IRA-International Journal of Management \& Social Sciences

ISSN 2455-2267; Vol.07, Issue 02 (2017)

Pg. no. 309-319

Institute of Research Advances

http://research-advances.org/index.php/RAJMSS

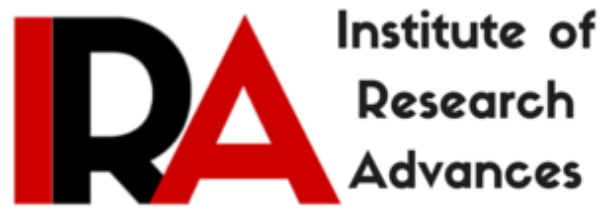

\title{
Efficient Model Selection for Nifty Index and Impact of Money Supply, Gold and Exchange Rate on S\&P Nifty 50
}

\section{Vishweswarsastry V.N}

Assistant Professor, Dept of PG, Presidency College, \#33/2C \& 33/2D,

Kempapura, Hebbal, Bengaluru -560024, Karnataka, India.

\section{Dr. Binoy Mathew}

Associate Professor, Dept. of MBA, Visvesvaraya Technological University,Centre for Post Graduate Studies, Bangalore Region,Visvesvaraya Institute of Advanced Technologies (VIAT),Muddenahalli, ChikkaballapurDist.,Karnataka State - 562101, India.

\section{Aisha Banu}

Assistant Professor, Presidency College, \#33/2C \& 33/2D,

Kempapura, Hebbal, Bengaluru -560024, Karnataka, India.

Type of Review: Peer Reviewed.

DOI: http://dx.doi.org/10.21013/jmss.v7.n2.p22

\section{How to cite this paper:}

V.N, Vishweswarsastry., Mathew, B., \& Banu, A. (2017). Efficient Model Selection for Nifty Index and Impact of Money Supply, Gold and Exchange Rate on S\&P Nifty 50. IRA-International Journal of Management \& Social Sciences (ISSN 2455-2267), 7(2), 309-319. doi:http://dx.doi.org/10.21013/jmss.v7.n2.p22

(C) Institute of Research Advances

(cc) EY-NC

This work is licensed under a Creative Commons Attribution-Non Commercial 4.0 International License subject to proper citation to the publication source of the work.

Disclaimer: The scholarly papers as reviewed and published by the Institute of Research Advances (IRA) are the views and opinions of their respective authors and are not the views or opinions of the IRA. The IRA disclaims of any harm or loss caused due to the published content to any party. 


\section{ABSTRACT}

The economic importance of stock market results from marketability which is increased or increasing resulting from quotation of shares from a stock exchange. Stock Indices attracts most of the investors and volatile to market conditions which affects the return of the investors. The primary objective of the paper is to study the effect of macroeconomic factors on NIFTY secondly to analyse and check the stationarity among various economic indicators and Nifty and thirdly to judge the best model for estimating the nifty. The methodology applied for the study is analytical and an econometric tool like ADF test, ARDL, Pairwise granger causality test and VAR is applied for regressing the index. The Variables was stationary at first order of difference for the nifty to regress for future period which aids investors in decision making.

Keywords:NIFTY 50, ADF, ARDL, VAR, Stationarity, Granger causality test, Differencing.

JEL classification: C20,C22,C51, G10, G17, F62

\section{Introduction}

Stock exchange is a market where stocks are placed by companies and traded by retail investors and institutional investors for better returns which beats inflation and helps investors in real returns over future period. As stocks has a capability in generating higher returns one should not forget the risks it causes in the falling market conditions. The stock market NIFTY 50 comprising highest market capitalization companies and known as Key benchmark Index is taken as Benchmark by most of the Retail investors and QIPs for other mid cap and small cap companies as well. NSE enjoys a dominant share in spot trading with $70 \%$ of market share. The market as a component of time series has a tendency to fluctuate over a time and makes most of the investors worry about their Investments. The market also volatiles due to macroeconomic variables. This paper emphasis the changes in the price of nifty due to various macroeconomic indicators like M3, exchange rates and Gold. The vector Auto regression model is primarily used along with ARDL, granger causality test to obtain the results.

\section{REVIEW OF LITERATURE}

1. Sinha, Iftaqar $(2016)^{1}$ : In this paper two macro variables i.e. Gross Domestic Product \& Exchange Rate are taken and data is collected for 12 months for the year 2014 from the website of RBI and SEBI. The data collected has been analyzed by using SPSS through correlation, regression and ANOVA in order to draw meaningful information. The findings show that GDP is the significant predictor and Exchange Rate is not the significant predictor of BSE Sensex.

2. Reddy $(2016)^{2}$ : In this research the primary focal area for examination is to determine model for gold price in which it is done through Box-Jenkins, ARIMA (Autoregressive Integrated Moving Average) and time series analysis model of forecasting. The main objective of this research was to investigate the factors which influence gold price of the gold market. Data for analysis is collected from variable data sources in order to examine the impact and contribution of factors on gold price. The research recommends that strategies address the reasons for expansion and give elective venture chances for retail financial specialists might better serve the target of reducing gold imports.

3. Subramanian $(2015)^{3}$ : This research paper investigates the following variables: stock market index (Sensex), GDP, Inflation, CRR, Index on industrial production \& USD (US dollars, Forex). The data analysis has shown that macro economic variables are influencing the Sensex. 
4. Mohanamani, Sivgnanasithi (2014) ${ }^{4}$ : This study investigates the impact of macroeconomic variables on the behavior of Indian Stock market such as BSE Sensex, Call Money rate, Exchange rate between Indian Rupees and US dollar, Foreign Institutional Investment, Industrial productivity, money supply and whole sale price index over the period 2006:04 to 2013:07. Descriptive Statistics, Pearson's correlation matrix, Unit root test and Granger Causality tests have been applied. The analysis reveals that Indian stock market is positively whole sale price index, money supply and industrial productivity. The exchange rate and inflow of foreign institutional investment are found to be insignificant to Indian Stock market. In the Granger Causality sense, whole sale price index and industrial productivity influence the stock market to a great extent.

5. Kulshrestha $(2014)^{5}$ : This paper examines whether market movement can be explained by foreign institutional investors and their impact on the capital markets. The present paper is an attempt to find out determinants of foreign institutional investment in India, a country that opened its economy to foreign capital due to their foreign exchange crisis. The objective of the study is to find out whether there exist relationship between FII and Indian capital market. The study conducted observed that investments by FIIs and the movements of BSE Sensex and CNX nifty are quite closely correlated. According to findings and results, foreign institutional investors (FIIs) have significant impact on the movement of Indian capital market.

6. Amalendu $(2013)^{6}$ : The research investigated the co-integration relationships among crude oil price, domestic gold price and selected financial variables (exchange rates and stock price indices) in India. ADF unit root test, Johansen co-integration analysis and Granger causality test have been designed to analyse the data. Johansen co-integration test result indicates that there exists a long-term relationship among the selected variables. Granger causality test result shows that there must be either bidirectional or no causality among the variables.

7. Bhunia, Mukhuti (2013) ${ }^{7}$ : The present research paper examines the impact of domestic gold price on stock price indices in India. Unit root test indicates that time series are not stationary at levels and the selected time series are stationary at 1 st difference. Granger causality test illustrate that no causality exists between nifty and gold price, gold price and Sensex and nifty and Sensex and bidirectional causality exists between gold price and nifty, Sensex and gold price and Sensex and nifty.

8. Gulati, Saini, Jain $(2013)^{8}$ : This paper attempts to project the likely impact of robust monsoon rains of 2013 on the Agricultural Gross Domestic Product (GDP) growth in India. A log-linear model fitted over 1996-97 to 2012-13 period can explain 95 percent of the variations in agri-GDP with all variables being statistically significant. The model also forecasts that the agri-GDP growth rate for the agricultural year (July-June) 2013-14 is likely to be between 5.2\% and 5.7\%. An alternative model to double check the results is also used. In this model, the AGCF is replaced by a simple trend variable. This model also suggests that the agri-GDP growth will be between $5.1 \%$ and $5.6 \%$.

9. Tabassum, Pardhasaradhi (2012) ${ }^{9}$ : This paper makes an attempt to study the relationship and impact of FDI \& FII on Indian stock market using statistical measures correlation coefficient and multi regression. Based on 11 years data starting from 2001 to 2011, it was found that the flow of FDI \& FII was moving in tandem with Sensex and Nifty. The study shows evidence that there is a strong positive correlation between FDI \&Sensex and FDI \& nifty and moderate positive correlation between FII \&Sensex and FII.

10. Reddy (2012) ${ }^{10}$ : This study was undertaken to observe the impact of inflation, GDP and interest rates on stock market returns and unearth the nature and strength of relationship between variable 
under study . A regression analysis showed that the explanatory variables accounted for $95.6 \%$ of the variation in stock prices. While a reduction in interest and inflation rate resulted in increased stock prices, increased RDGP has a positive impact.

11. Sinha, Gupta, Randev (2010) ${ }^{11}$ : This paper examines the state of the Indian economy pre, during and post-recession by analyzing various macro economic factors such as GDP, exchange rate, inflation, capital markets and fiscal deficit. ARIMA modeling is used to analyse the data. The findings indicate that Indian economy is reviving after a slowdown during the period of global recession. It is forecasted that GDP, foreign investments, fiscal deficit and capital markets will rise in 2010-11. Furthermore, the rupee-dollar exchange rate will not change much during the same period.

12. Singh $(2010)^{12}$ : In this research paper, attempt has been made to explore the relation especially the causal relation between stock market index i.e. BSE Sensex and three key macro economic variables of Indian economy by using correlation, unit root stationarity tests and Granger causality test. Results showed that the stock market index, the industrial production index, exchange rate, and wholesale price index contained a unit root and were integrated of order one. The Granger causality test indicated that IIP is the only variable having bilateral causal relationship with BSE Sensex. WPI is having strong correlation with Sensex but it is having unilateral causality with BSE Sensex. Therefore, it is concluded that, Indian stock market is approaching towards informational efficiency at least with respect to two macroeconomic variables, viz. exchange rate and inflation (WPI).

13. Nusrat $(2009)^{13}$ : This paper attempts to understand the inter linkage and the causal relationship between the stock market and the manufacturing sector in India. Engel-Granger co-integration test is applied to measure the long-term relationship between two variables, Granger causality test is used to check the short-term causal relationship. The analysis reveals that there is a long-term relationship between the stock market and the manufacturing sector, \& in short-term, causality runs from BSE Sensex to IIP.

14. Patel ( 2012) ${ }^{14}$ : The study investigates the effect of macroeconomic determinants on the performance of the Indian Stock Market using monthly data over the period of 20years (19912011). The result of the analysis shows that there exists a long run equilibrium relation between stock market indices and all macroeconomic variables. It also provides evidence of causality running from exchange rate to stock market indices to IIP \& Oil Prices.

15. Gurloveleen $\mathrm{K}$ and Bhatia $\mathrm{BS}^{15}$ : The study focused on impact of macroeconomic variables on the functioning of Indian stock market. The ADF test, multiple regression and granger causality tests were employed to find out the results. It was found from their study that Foreign exchange reserve, gross fiscal deficit, inflation rate and trade balance at $1^{\text {st }}$ difference and broad money and IIP at $2^{\text {nd }}$ difference. Their study had an outcome that stock market was a weak form efficient because no relationship was found amongst the variables during the study period.

\section{Objectives of the study}

1 To study the effect of Selected Macroeconomic indicators on S\&P CNX Nifty 50Index.

2. To study the stationarity and stability of various economic indicators along with Nifty 50 .

3. To test the validity of model for forecasting nifty. 


\section{HYPOTHESIS}

Ho - There is no significant relationship between variables and Nifty.

$\mathrm{Ha}$ - There is significant relationship between variables and Nifty.

\section{RESEACH GAP}

The factors that are taken into consideration for the purpose of research are not been observed by the authors. The research has been extended for about ten years in the research made. The forecast has been made based on Econometric model. The research mainly brings in whether there is significant relationship between variables and Sensex.

\section{ANALYIS AND INTERPRETATION}

\section{Normality Test:}

Ho: Data is Normal

H1: Data is non normal

Graph1: Showing normal distribution plot along with the test results

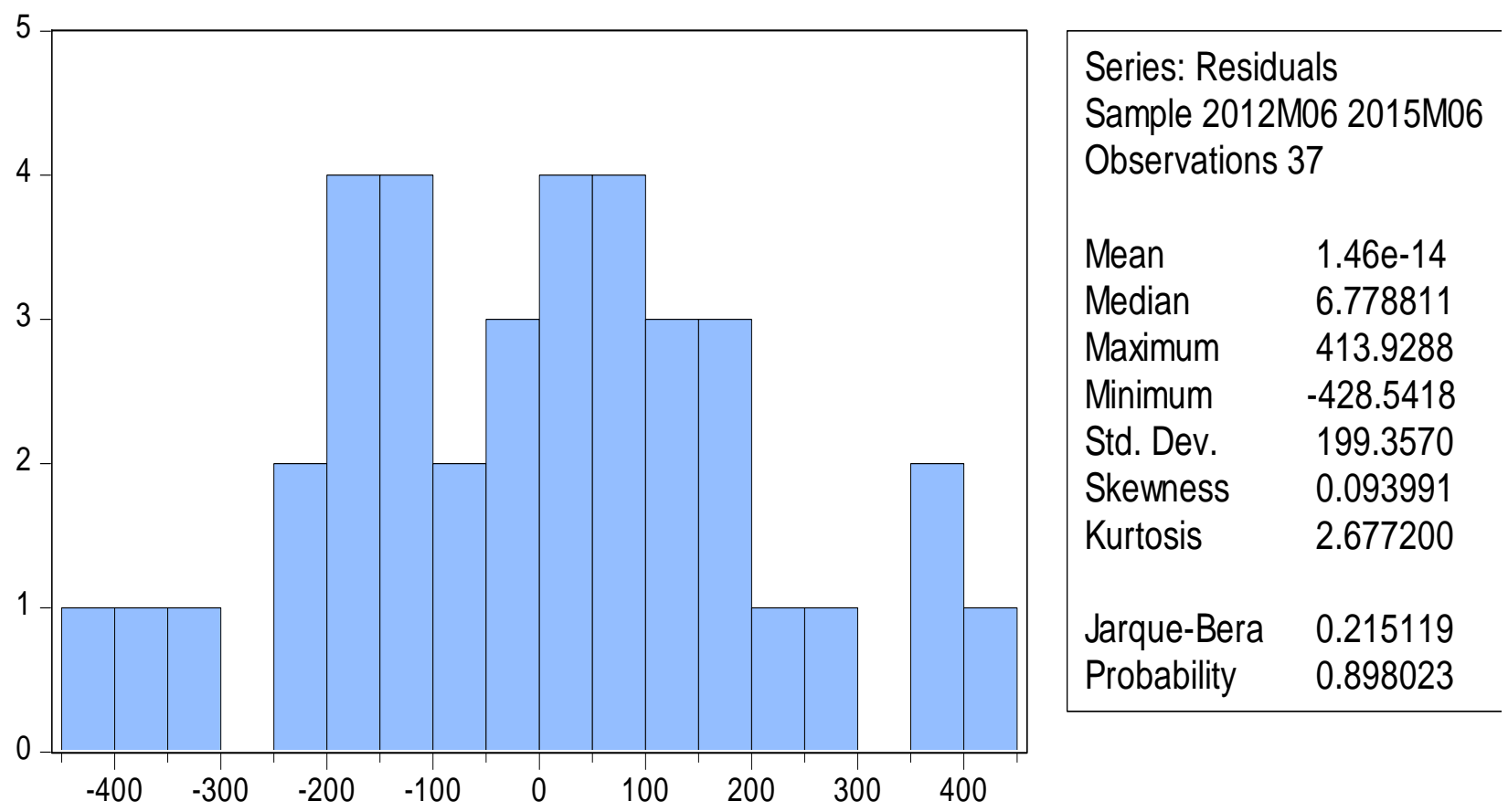

From the above analysis the data is said to be normally distributed. The results of Normal distribution particularly the JarqueBera test showed the P-value above 5\% indicating the normality of the data. Though most of the timeseries data are not normally distributed researchers have a tendency to continue for stationarity tests directly. The normality is a step ahead of stationarity and should consider for model building which helps in accurate estimation of the selected variables.

\section{Stationarity Test:}

Ho: Nifty has unit root or not stationary 
H1: Nifty does not have unit root or stationary

\section{Unit root test: ADF}

Null Hypothesis: D(NIFTY) has a unit root

Exogenous: Constant

Lag Length: 0 (Automatic - based on SIC, maxlag=9)

\begin{tabular}{llll}
\hline \hline & t-Statistic & Prob.* \\
\hline \hline Augmented Dickey-Fuller test statistic & -6.410793 & 0.0000 \\
\hline Test critical values: & 1\% level & -3.621023 & \\
& 5\% level & -2.943427 & \\
& 10\% level & -2.610263 &
\end{tabular}

The NIFTY data was extracted from the year April 2012 - June 2015. With the estimation of Augmented Dickey-Fuller test the data was significant at the $1^{\text {st }}$ difference using the intercept with the probability value of $0.0000 \%$ which is less than the $5 \%$ level of significance.

\section{VAR-Vector Auto Regression}

Vector Auto Regression is an economic model used to capture the linear interdependencies among multiple times series of data. Vector auto regression is used to interpret the univariate autoregressive model by allowing for more than one evolving variable. From the above analysis of the study the dependent variables such as NIFTY, and independent Exchange rate, Gold, M3 are stationary at the $1^{\text {st }}$ difference using the intercept. According to the VAR Model the linear interdependencies among multiple times series of data are used.

VAR Lag Order Selection Criteria

Endogenous variables: DNIFTY DM3 DGOLD

DEX_RATE

Exogenous variables: $\mathrm{C}$

Date: 05/06/16 Time: 12:55

Sample: 2012M04 2015M06

Included observations: 35

\begin{tabular}{lllllll}
\hline \hline Lag & LogL & LR & FPE & AIC & SC & HQ \\
\hline \hline 0 & -837.5298 & NA* & $9.00 \mathrm{e}+15^{*}$ & $48.08742^{*}$ & $48.26517 *$ & $48.14878^{*}$ \\
1 & -823.9740 & 23.23841 & $1.04 \mathrm{e}+16$ & 48.22709 & 49.11586 & 48.53389 \\
2 & -812.0821 & 17.66799 & $1.37 \mathrm{e}+16$ & 48.46184 & 50.06162 & 49.01408 \\
3 & -799.4380 & 15.89542 & $1.84 \mathrm{e}+16$ & 48.65360 & 50.96440 & 49.45129 \\
\hline \hline
\end{tabular}

\section{ARDL Model}

Dependent Variable: DNIFTY

Method: Least Squares

Date: 05/06/16 Time: 12:57

Sample (adjusted): 2012M06 2015M06

Included observations: 37 after adjustments 
DNIFTY $=\mathrm{C}(1) * \mathrm{DNIFTY}(-1)+\mathrm{C}(2) * \mathrm{DM} 3(-1)+\mathrm{C}(3) * \mathrm{DGOLD}(-1)+\mathrm{C}(4)$

*DEX_RATE(-1) + C(5)

\begin{tabular}{lllll}
\hline \hline & Coefficient & Std. Error & t-Statistic & Prob. \\
\hline \hline $\mathrm{C}(1)$ & 0.038519 & 0.223309 & 0.172494 & 0.8641 \\
$\mathrm{C}(2)$ & 0.018415 & 0.062941 & 0.292575 & 0.7717 \\
$\mathrm{C}(3)$ & 0.082237 & 0.045846 & 1.793779 & 0.0823 \\
$\mathrm{C}(4)$ & -22.77048 & 38.54290 & -0.590783 & 0.5588 \\
$\mathrm{C}(5)$ & 78.18068 & 76.84135 & 1.017430 & 0.3166 \\
\hline \hline R-squared & 0.095681 & Mean dependent var & 87.27297 \\
Adjusted R-squared & -0.017359 & S.D. dependent var & 209.6383 \\
S.E. of regression & 211.4500 & Akaike info criterion & 13.67094 \\
Sum squared resid & 1430755. & Schwarz criterion & 13.88863 \\
Log likelihood & -247.9124 & Hannan-Quinn criter. & 13.74769 \\
F-statistic & 0.846435 & Durbin-Watson stat & 2.024816 \\
Prob(F-statistic) & 0.506315 & & \\
\hline \hline
\end{tabular}

The test is used for finding out the long term relationship among the variables. The VAR model's equation is used consisting of all the variables to estimate ARDL model. In the above analysis it is interpreted that only $\mathrm{C}(3)$ is significant at $10 \%$ level of significance with the p-value is $8.23 \%$. Other than $\mathrm{C}(3)$ Gold all other factors are more than $5 \%$ of $10 \%$ level of significance were this clearly states that no factors has any impact on NIFTY.

5. HETEROSKEDASTICITY TEST: BREUSCH-PAGAN-GODFREY

Heteroskedasticity Test: Breusch-Pagan-Godfrey

\begin{tabular}{llll}
\hline \hline F-statistic & 1.198367 & Prob. F(4,32) & 0.3306 \\
Obs*R-squared & 4.820374 & Prob. Chi-Square(4) & 0.3062 \\
Scaled explained SS & 3.023654 & Prob. Chi-Square(4) & 0.5539 \\
\hline \hline
\end{tabular}

Test Equation:

Dependent Variable: RESID^2

Method: Least Squares

Date: 05/06/16 Time: 12:59

Sample: 2012M06 2015M06

Included observations: 37

\begin{tabular}{lllll}
\hline \hline Variable & Coefficient & Std. Error & t-Statistic & Prob. \\
\hline \hline C & 35561.95 & 18249.83 & 1.948618 & 0.0602 \\
DNIFTY(-1) & -49.34733 & 53.03586 & -0.930452 & 0.3591 \\
DM3(-1) & 7.412538 & 14.94860 & 0.495868 & 0.6234 \\
DGOLD(-1) & -20.98271 & 10.88837 & -1.927076 & 0.0629 \\
DEX_RATE(-1) & -1022.549 & 9153.944 & -0.111706 & 0.9118 \\
\hline \hline R-squared & 0.130280 & Mean dependent var & 38669.07 \\
Adjusted R-squared & 0.021565 & S.D. dependent var & 50769.83 \\
S.E. of regression & 50219.41 & Akaike info criterion & 24.61128
\end{tabular}




\begin{tabular}{llll} 
Sum squared resid & $8.07 \mathrm{E}+10$ & Schwarz criterion & 24.82897 \\
Log likelihood & -450.3087 & Hannan-Quinn criter. & 24.68803 \\
F-statistic & 1.198367 & Durbin-Watson stat & 2.153651 \\
Prob(F-statistic) & 0.330561 & & \\
\hline
\end{tabular}

Breusch-Pagan Godfrey test was developed in the year 1979which is used for heteroskedasticity for a linear regression model. It tests whether the estimated variance of the residuals from a regression are dependent on the values of the independent variables. In that case it means its heteroskedasticity. In other words heteroskedasticity means that the variables are scattered and doesn't have a linearity which is no favourable for the analysis.

As per the above test of Heteroskedasticity Test: Breusch-Pagan-Godfrey, it clearly signifies that the Observed R Square is 4.82 and the Chi Square is at $30.62 \%$ or it is at the p value of 0.3062 which states that there is linearity in the data and there is no heteroskedasticity. It is found that the economic variables in the test also has no heteroscedasticity were in all the variables are more than $0.05 \mathrm{p}$ value or more than $5 \%$ level of significance.

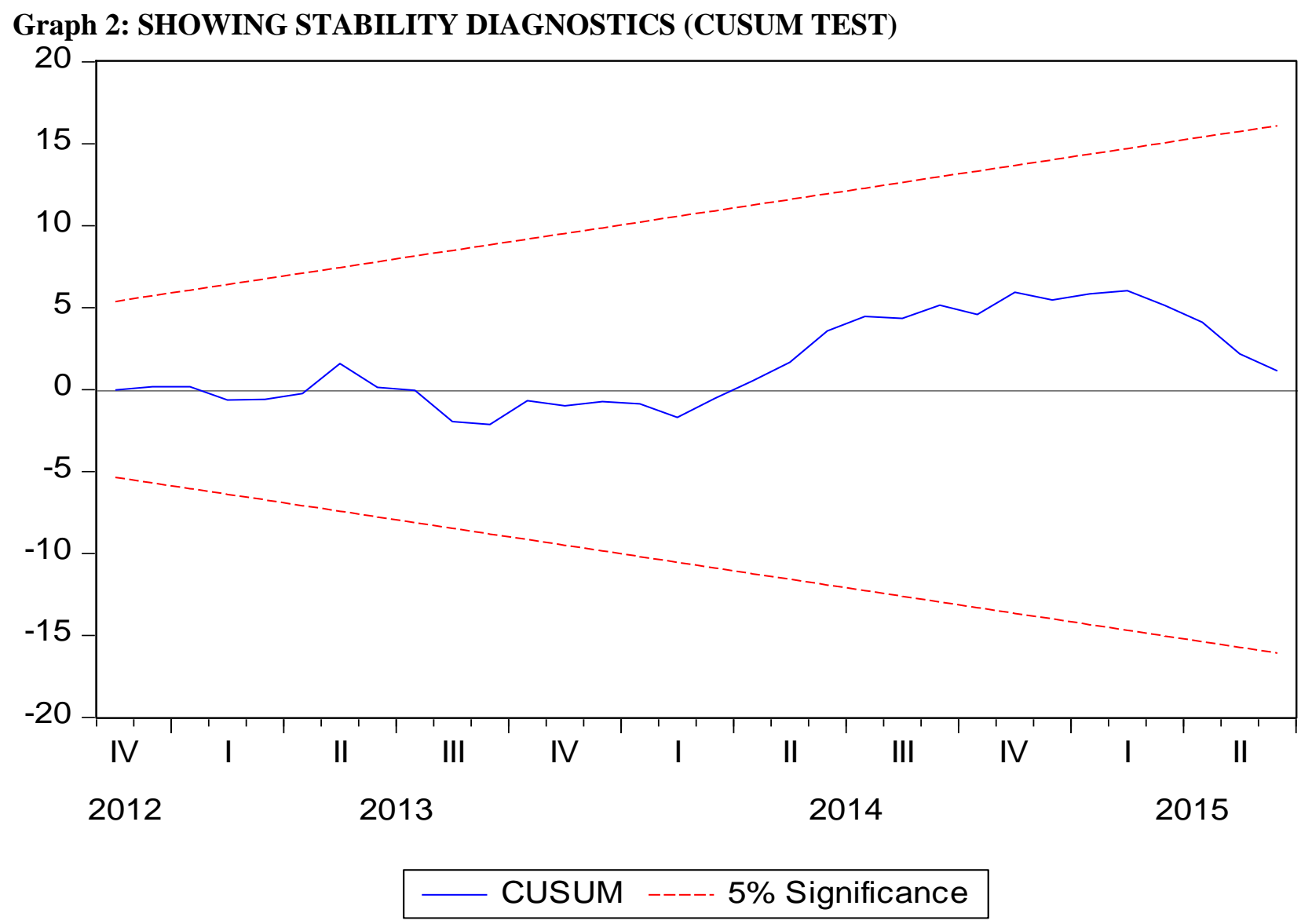

The CUSUM test (Brown, Durbin, and Evans, 1975) is based on the cumulative sum of the recursive residuals. This option plots the cumulative sum together with the $5 \%$ critical lines. The test finds parameter instability if the cumulative sum goes outside the area between the two critical lines. From the above graph the cumulative sum (blue line) is with in the 5\% critical line which clearly specifies that there is stability with the data as per the ARDL model. 


\section{PAIRWISE GRANGER CAUSALITY TESTS}

Pairwise Granger Causality Tests

Date: 05/06/16 Time: 13:02

Sample: 2012M04 2015M06

Lags: 1

\begin{tabular}{lcccc}
\hline \hline Null Hypothesis: & Obs & \multicolumn{2}{c}{ F-Statistic } & Prob. \\
\hline \hline DM3 does not Granger Cause DNIFTY & 37 & 0.00695 & 0.9341 \\
DNIFTY does not Granger Cause DM3 & & 0.06595 & 0.7989 \\
\hline \hline DGOLD does not Granger Cause DNIFTY & 37 & 2.91611 & 0.0968 \\
DNIFTY does not Granger Cause DGOLD & & 0.17544 & 0.6780 \\
\hline \hline DEX_RATE does not Granger Cause DNIFTY & 37 & 0.07518 & 0.7856 \\
DNIFTY does not Granger Cause DEX_RATE & & 0.44077 & 0.5112 \\
\hline \hline DGOLD does not Granger Cause DM3 & 37 & 0.98967 & 0.3269 \\
DM3 does not Granger Cause DGOLD & & 10.0033 & 0.0033 \\
\hline \hline DEX_RATE does not Granger Cause DM3 & 37 & 3.71451 & 0.0623 \\
DM3 does not Granger Cause DEX_RATE & & 0.02493 & 0.8755 \\
\hline \hline DEX_RATE does not Granger Cause DGOLD & 37 & 1.13719 & 0.2938 \\
DGOLD does not Granger Cause DEX_RATE & & 5.68660 & 0.0228 \\
\hline \hline
\end{tabular}

From the above analysis of Pairwise Granger Causality it's found that the Gold is influencing NIFTY in one direction (DGOLD does not Granger Cause DNIFTY) at $0.0968 \mathrm{p}$ value or $9.68 \%$ at $10 \%$ level of significance. The M3 is also influencing the Gold in one direction (DM3 does not Granger Cause DGOLD) at the $\mathrm{p}$ value of 0.0033 or at $0.33 \%$ which is below $5 \%$ level of significance which will have a greater impact. It is also seen that the Exchange Rate also has an influence on M3 (DEX_RATE does not Granger Cause DM3) at 10\% level of significance with the $\mathrm{p}$ value at 0.0623 or $6.23 \%$ which is ane direction. With Exchange Rate influencing the M3 it's also seen that the Exchange Rate is influenced by the Gold (DGOLD does not Granger Cause DEX_RATE). The p value of Gold influencing Exchange Rate is at 0.0228 or $2.28 \%$ which is at the $5 \%$ level of significance.

\section{FINDIINGS}

- It was found that the economical variable such as Gold, M3 and Exchange Rate was found stationary at the $1^{\text {st }}$ difference using the intercept in the Augmented Dickey Fuller test.

- After the estimation of Lag Length Criteria post Vector Auto regression Model with 2 lag it was found that the Akaike information criterion results the lag criteria for the Vector Auto regression Model is either to be 0 or 1

- It was analyzed that NIFTY with other dependent variables estimation of Vector Auto regression and ARDL model, it resulted that the entire economical variable had the $\mathrm{p}$ value more that $5 \%$. Hence forth it significates that no variables have serial correlation.

-In the analysis of Histogram - Normality Test the JarqueBera and Probability was more than 5\% which means that the data is normally distributed.

- In the heteroscedasticity test it was found that the all the variables are more than the $\mathrm{p}$ value of $5 \%$ were it results that there is no heteroscedasticity with the economic variables. 
- In the Stability Diagnostics (Cusum Test) 5\% critical lines. It's found that the parameter stability of cumulative goes inside the 5\% critical line area between the two critical lines. Hence it is proven that the data is has a good stability.

- It was also found in the Pairwise Granger Causality that M3 is influencing the Gold in one direction at the p value of 0.0033 or at $0.33 \%$ which is below $5 \%$ level of significance which will have a greater impact.

- .It is also found that Exchange Rate influenced by Gold at the p value of 0.0228 or $2.28 \%$ which is at the $5 \%$ level of significance at one direction.

- The dependent variable NIFTY was found stationary at $1^{\text {st }}$ difference using intercept with $\mathrm{p}$ value lesser then 5\% which result to have linearity with the other dependent economic variables.

- The Index of Industrial Production and Call Money were stationary at level with the $p$ value lesser than 5\% which is not eligible for the further interpretation due to non-linearity.

- After the estimation of the Granger causality/Block Extogeneity it was found that gold is impacting the NIFTY over the other variables. The impact on NIFTY by the Gold is at 0.0728 value.

- After Pairwise Granger Causality it's found that the Gold is influencing NIFTY in one direction (DGOLD does not Granger Cause DNIFTY) at $0.0968 \mathrm{p}$ value or $9.68 \%$ at $10 \%$ level of significance.

- The Exchange Rate is found to be influenced M3 at $10 \%$ level of significance with the $\mathrm{p}$ value at 0.0623 or $6.23 \%$ which is at one direction

\section{CONCLUSION}

For every economy and for the company's also index play a vital role for their growth and there business condition which is affected by the economic factors. Boom in the market signifies the growth and the recession happens when the market crashes. From the above study of macro-economic factors affecting NIFTY Index, it was found that the Gold has an impact on the NIFTY Index. The study's objective was to investigate and analyze to find which factor had a greater impact on the NIFTY Index. The objective was also to find out which factor had the long term relationship towards NIFTY Index by using the test like Granger Causality with Vector Auto regression. The study analysis that the economical variable Gold has a long term relationship by affecting the NIFTY Index. The study uses the ARDL Model in estimation the significance of macro-economic factors towards the NIFTY Index. The study uses the Lag 1 after the estimation of Lag Length Criteria. The sample of the study was from April 2012-June 2015. From using ARDL model it is concluded that overall Gold is affected from some variables which proved to be significant influencing the volatility. It was also found out after the Granger Causality/Block Exogeneity Wald Tests and Pairwise Granger Causality test it was found Gold has a strong impact on the NIFTY Index.

\section{REFERENCES}

1. Sinha. Dr Jyotsna, Ahmad. Iftagar, (2016), "A study on relationship between macro-economic variables and stock market performance with reference to BSE-Sensex", International Journal of Applied Research, 2(2), 10-13.

2. Dhanalakshmi.P.M, R.R.S. Reddy, (2016), "An analytical study on forecasting model with special attention to gold prices", International Journal of Advance Research, Idea \& Innovations in Technology, 2(3), 1-9.

3. Subramanian. M, (2015), "A study on Impact of macro-economic variables in stock market", SSRG International Journal of Economics and Management Studies, 2(5), 25-33.

4. P.Mohanamani, Sivagnanasithi. T, (2014), "Indian Stock market and Aggregate macro-economic variables: Time Series Analysis", IOSR Journal of Economics \& Finance, 3(6), 68-74. 
5. Kulshrestha. Hemkant, (2014), "Impact of Foreign Institutional Investors (FIIs) on Indian Capital Market", IMPACT: International Journal of Research in Business Management", 2(3), 35-52.

6. Bhunia. Amalendu, (2013), "Cointegration \& Causal Relationship among crude price, domestic gold price and financial variables - an evidence of BSE \& NSE", Journal of Contemporary Issues in Business Research, 2(1), 1-10.

7. Bhunai. Amalendu, Mukhuti. Somnath, (2013), "The impact of domestic gold price on stock price indices an empirical study of Indian Stock Exchanges", Universal Journal of Marketing \& Business Research, $2(2), 35-43$.

8. Gulati. Ashok, Saini. Shweta, Jain.Surbhi, (2013), "Monsoon 2013: Estimating the impact on Agriculture", Indian Council for Research on International Economic Relations, Working Paper.

9. Sultana. Tabassum. Syed, Pardhasaradhi. S, (2012), "Impact of Flow of FDI \& FII on Indian Stock Market”, Finance Research, 1(3), 4-10.

10. Reddy. Lokeshwar.V, (2012), "Impact of inflation \& GDP on stock market returns in India", International Journal of Advanced Research in Management \& Social Sciences, 1(6), 120-136.

11. Sinha. Pankaj, Gupta. Sushant, Randev. Nakul, (2010), "Modeling \& Forecasting of Macro-Economic Variables of India: before, during \& After Recession", MPRA, https://mpra.ub.unimuenchen.de/26539/MPRA Paper No.26539.

12. Singh. Dharmendra, (2010), "Causal Relationship between macro-economic variables \& Stock market: A case study for India”, Pakistan Journal of Social Sciences, 30(2), 263-274.

13. Ahmad. Nusrat, (2009), "Linkage Between stock market \& Manufacturing Sector in India: A time series analysis", The ICFAI Journal of Applied Finance, 15(1), 43.

14. Patel. Samveg, (2012), "The effect of macro economic determinants on the performance of the Indian Stock Market”, NMIMS Management Review, Vol 22, 117-127.

15. Kumari. J, Mahakud.(2012) "Relationship between Stock prices, exchange rate \& the demand for money in India," Economic, Management \& Financial Markets, 7(3), 31-52

16. Ghosh A. (2011), "Forecasting BSE Sensex under Optimal conditions: An investigation post factor analysis”, Journal of Business Studies Quarterly, 3(2), 57-73.

17. Yahyazadehfar. M, Babaie. A, (2012), "Macroeconimic variables \& stock price: new evidence from Iran, Middle-East Journal of Scientific Research", 11(4), 408-415.

18. Agarwalla. RK, (2006), "Share prices \& macroeconomic variables in India: an approach to investigate the relationship between stock markets \& economic growth", project report, working paper, Business Systems \& Cybernetics Centre, Tata Consultancy Services Limited, 1-20

19. Kaliyamoorthy. S, Parithi. S, (2012), "Relationship of Gold Market \& Stock market: an Analysis", International Journal of Business \& Management Tomorrow, 2(6), 1-6,

20. Mohanty. B, Bhanumurthy. NR, (2014), "Exchange rate regimes and inflation: evidence from India", International Economic Journal, 28(2), 311-332.

21. Shrikanth.Maram, Kishore. Braj,(2012), "Net FII Flows into India: A cause \& effect study", ASCI Journal of Management, 41(2), 107-12

22. Loomba, Jatinder, (2012), "Do FIIs impact volatility of Indian stock market?", Internatioanl Journal of Marketing, Financial services \& management research, 1(7). 